\title{
Teaching NeuroImages: Rare Adult-Onset Genetic Leukoencephalopathy
}

Pavankumar Rudrabhatla, MD, Sekar Sabarish, MD, Harikrishnan Ramachandran, MD, and Sruthi S. Nair, MD, DM

Neurology ${ }^{\circledR}$ 2021;96:e2561-e2562. doi:10.1212/WNL.0000000000011233

Figure 1 Core Features in T2, T2-Fluid-Attenuated Inversion Recovery (FLAIR), and T1 MRI Sequences

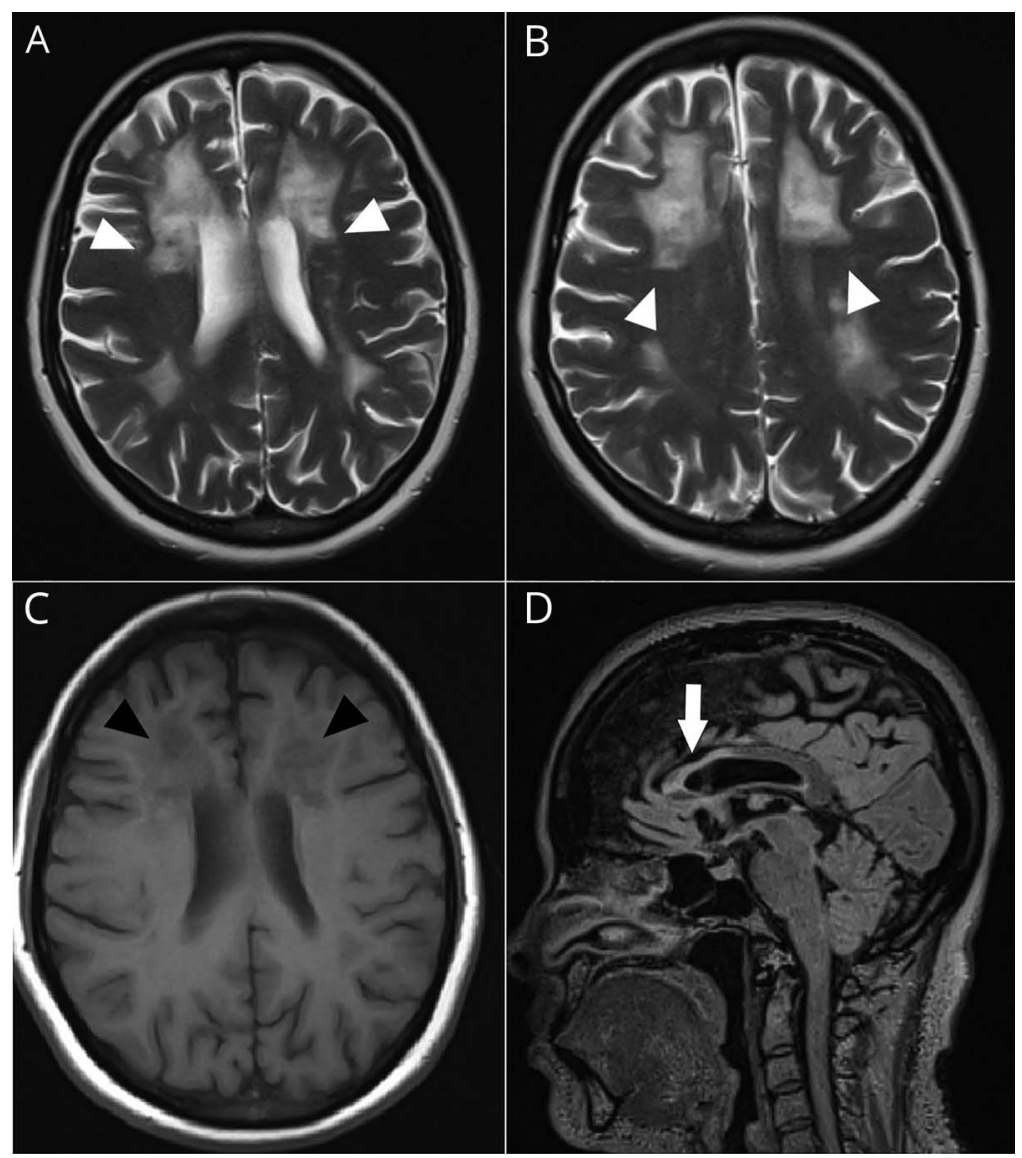

Axial T2-weighted images (A, B) show confluent symmetric frontal-predominant white matter hyperintensities sparing subcortical U-fibers (white arrowheads), hypointense in T1-weighted sequences ( $C$, black arrowheads). Sagittal T2-FLAIR (D) shows corpus callosum hyperintensities and atrophy (arrow).

A 34-year-old woman presented with a 1-year history of progressive apathy, executive dysfunction, and memory impairment. Examination revealed moderate frontal dysfunction and bipyramidal signs. MRI brain (figure 1) showed a symmetric leukoencephalopathy sparing subcortical U-fibers.

Evaluation for an acquired white matter disease was negative. Next-generation sequencing showed a pathogenic heterozygous missense mutation in exon 18 of CSF1R gene (p.Ile794Thr)
Correspondence

Dr. Sruthi S. Nair

sruthisn@sctimst.ac.in

\section{MORE ONLINE}

$\rightarrow$ Teaching slides

links.lww.com/WNL/

B278.

From the Departments of Neurology (P.R., H.R., S.S.N.) and Imaging Sciences and Interventional Radiology (S.S.), Sree Chitra Tirunal Institute for Medical Sciences and Technology, Trivandrum, Kerala, India.

Go to Neurology.org/N for full disclosures. Funding information and disclosures deemed relevant by the authors, if any, are provided at the end of the article. 


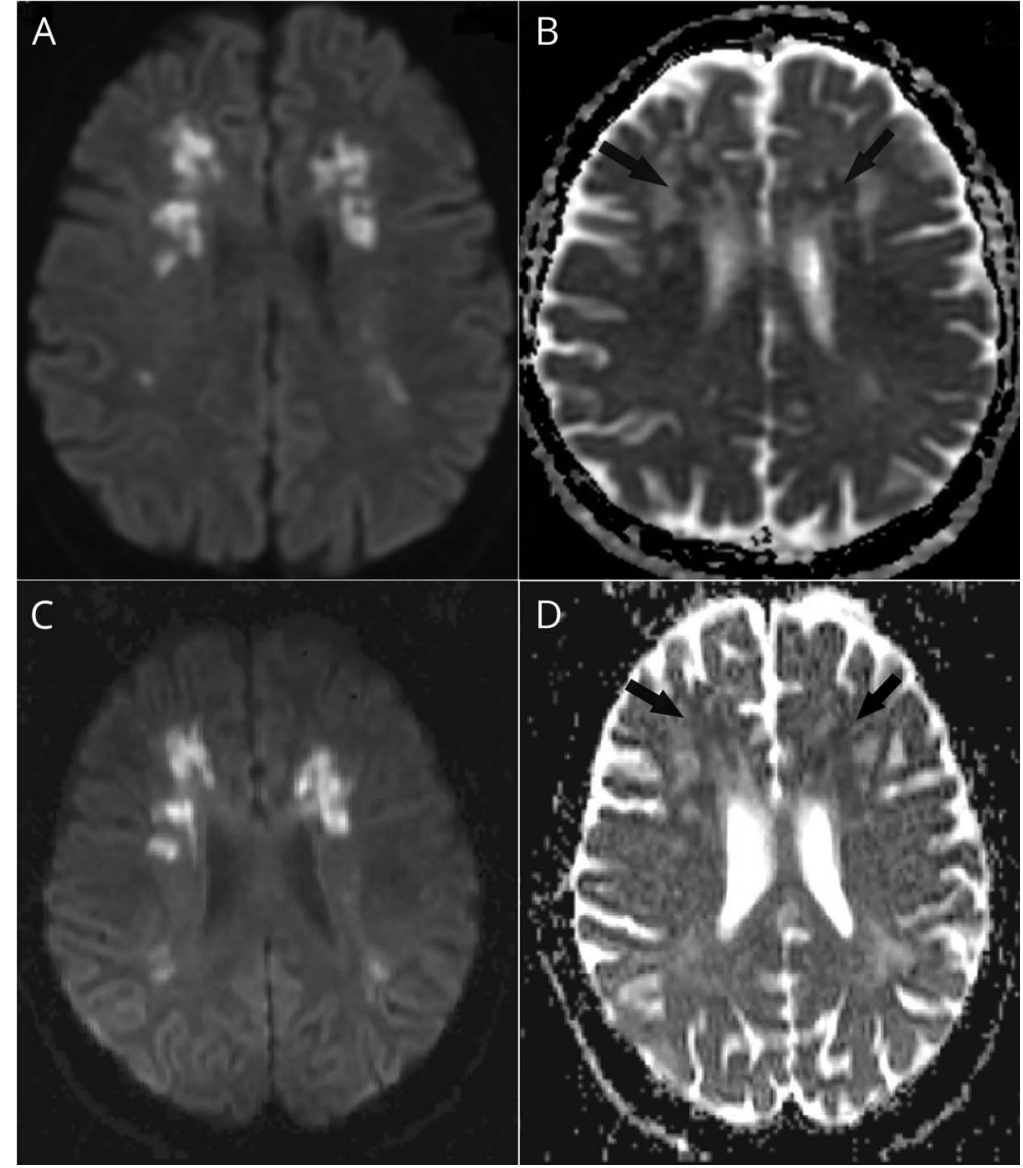

Diffusion-weighted images (A, B) show deep white matter diffusion restriction with corresponding low apparent diffusion coefficient (black arrows), persistent in similar sequences taken 4 months later (C, D). confirming the diagnosis of adult-onset leukoencephalopathy with axonal spheroids and pigmented glia (ALSP). Inheritance is autosomal dominant or sporadic. Presence of symmetric or asymmetric nonenhancing white matter lesions with persistent diffusion restriction (figure 2) and corpus callosum thinning differentiates ALSP from acquired demyelination. ${ }^{1,2}$

\section{Study Funding}

No targeted funding reported.

\section{Disclosure}

The authors report no disclosures relevant to the manuscript. Go to Neurology.org/N for full disclosures.

\section{Appendix Authors}

\begin{tabular}{|c|c|c|}
\hline Name & Location & Contribution \\
\hline $\begin{array}{l}\text { Pavankumar } \\
\text { Rudrabhatla, } \\
\text { MD }\end{array}$ & $\begin{array}{l}\text { Department of Neurology, Sree } \\
\text { Chitra Tirunal Institute for Medical } \\
\text { Sciences and Technology, } \\
\text { Thiruvananthapuram, Kerala, India }\end{array}$ & $\begin{array}{l}\text { Major role in acquisition } \\
\text { of data and drafting of } \\
\text { manuscript }\end{array}$ \\
\hline
\end{tabular}

\section{Appendix (continued)}

\begin{tabular}{|c|c|c|}
\hline Name & Location & Contribution \\
\hline $\begin{array}{l}\text { Sekar Sabarish, } \\
\text { MD }\end{array}$ & $\begin{array}{l}\text { Department of Imaging Sciences } \\
\text { and Interventional Radiology, Sree } \\
\text { Chitra Tirunal Institute for Medical } \\
\text { Sciences and Technology, } \\
\text { Thiruvananthapuram, } \\
\text { Kerala, India }\end{array}$ & $\begin{array}{l}\text { Major role in acquisition } \\
\text { of data and } \\
\text { interpretation of imaging } \\
\text { data }\end{array}$ \\
\hline $\begin{array}{l}\text { Harikrishnan } \\
\text { Ramachandran, } \\
\text { MD }\end{array}$ & $\begin{array}{l}\text { Department of Neurology, Sree } \\
\text { Chitra Tirunal Institute for Medical } \\
\text { Sciences and Technology, } \\
\text { Thiruvananthapuram, } \\
\text { Kerala, India }\end{array}$ & $\begin{array}{l}\text { Study concept and } \\
\text { design }\end{array}$ \\
\hline $\begin{array}{l}\text { Sruthi S. Nair, } \\
\text { MD, DM }\end{array}$ & $\begin{array}{l}\text { Department of Neurology, Sree } \\
\text { Chitra Tirunal Institute for Medical } \\
\text { Sciences and Technology, } \\
\text { Thiruvananthapuram, Kerala, India }\end{array}$ & $\begin{array}{l}\text { Study concept and } \\
\text { design, and critical } \\
\text { revision of manuscript }\end{array}$ \\
\hline
\end{tabular}

\section{References}

1. Adams SJ, Kirk A, Auer RN. Adult-onset leukoencephalopathy with axonal spheroids and pigmented glia (ALSP): integrating the literature on hereditary diffuse leukoencephalopathy with spheroids (HDLS) and pigmentary orthochromatic leukodystrophy (POLD). J Clin Neurosci 2018;48:42-49.

2. Konno T, Yoshida K, Mizuno T, et al. Clinical and genetic characterization of adultonset leukoencephalopathy with axonal spheroids and pigmented glia associated with CSF1R mutation. Eur J Neurol 2017;24:37-45. 


\section{Neurology}

Teaching NeuroImages: Rare Adult-Onset Genetic Leukoencephalopathy

Pavankumar Rudrabhatla, Sekar Sabarish, Harikrishnan Ramachandran, et al.

Neurology 2021;96;e2561-e2562 Published Online before print November 18, 2020

DOI 10.1212/WNL.0000000000011233

This information is current as of November 18, 2020

\section{Updated Information \&} Services

References

Subspecialty Collections

Permissions \& Licensing

Reprints including high resolution figures, can be found at: http://n.neurology.org/content/96/20/e2561.full

This article cites 2 articles, 0 of which you can access for free at: http://n.neurology.org/content/96/20/e2561.full\#ref-list-1

This article, along with others on similar topics, appears in the following collection(s):

All Cognitive Disorders/Dementia

http://n.neurology.org/cgi/collection/all_cognitive_disorders_dementia All Demyelinating disease (CNS)

http://n.neurology.org/cgi/collection/all_demyelinating_disease_cns Leukodystrophies

http://n.neurology.org/cgi/collection/leukodystrophies

Information about reproducing this article in parts (figures,tables) or in its entirety can be found online at:

http://www.neurology.org/about/about_the_journal\#permissions

Information about ordering reprints can be found online:

http://n.neurology.org/subscribers/advertise

Neurology ${ }^{\circledR}$ is the official journal of the American Academy of Neurology. Published continuously since 1951, it is now a weekly with 48 issues per year. Copyright () 2020 American Academy of Neurology. All rights reserved. Print ISSN: 0028-3878. Online ISSN: 1526-632X.

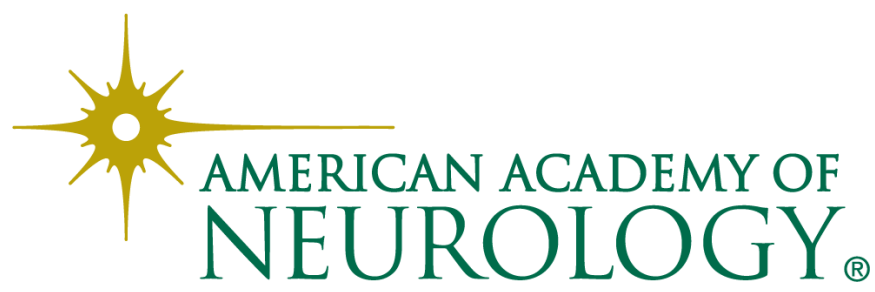

